\title{
THE EFFECTIVENESS OF PROJECT-BASED LEARNING AND PROBLEM- BASED LEARNING MODELS TOWARDS GEOGRAPHY LEARNING OUTCOMES IN TERMS OF STUDENTS' LOCUS OF CONTROL
}

\author{
Nur Hafidah Yuniar Sari ${ }^{1}$, Muhsinatun Siasah Masruri² \\ ${ }^{1}$ Student of Geography Education, Graduate School, Yogyakarta State University \\ ${ }^{2}$ Lecturer of Geography Education, Graduate School, Yogyakarta State University \\ Street. Colombo, No.1, Caturtunggal, Depok subdistrict of Sleman, Yogyakarta. \\ nurhafidah_yuniar@ymail.com
}

Received:1 October 2018/Revised:7 November 2018/Accepted: 1 December 2018/Published online:31

December 2018

\begin{abstract}
Nowadays, Indonesian's education seems to have an improvement in its quality. The government is establishing the 2013 curriculum. However, its implementation has not been well-implemented. In regard to this problem, it is necessary to apply scientific learning models: PjBL and PBL models. With these models and according to the students' locus of control, it is expected that it will improve students' learning outcomes. This study is aimed at determining the effectiveness of PjBL and PBL models towards learning outcomes in terms of the students' Locus of Control. The method used in this study was experiment, with $2 \times 2$ factorial design. The population was XI IPS students of SMAN 1 Ngaglik. The samples were 32 experimental students of PBL model and 28 experimental students of PjBL model. The data were collected using questionnaires and tests. The data were analyzed using Two Ways ANOVA. The result of the analysis shows that there is an influence between the models and students' locus of control towards the learning outcomes. The value of $\mathrm{F}_{\text {cal }} 5.488>\mathrm{F}_{\text {std }} 4.00$ and the value of the probability is $0.023<0.05$.
\end{abstract}

Keywords: Project-Based Learning, Problem-Based Learning, Learning Outcomes, Students' Locus of Control. 
Nur Hafidah Yuniar Sari, et all / GEOSI Vol 3. No. 3 (2018) 16-25

\section{Introduction}

Purwanto (2009: 1) states that education is a program that involves several interrelated components in a process to achieve the goals that have been set. Then, Sani (2017: 1), asserts that education gives students the possibility to get opportunities and knowledge in order to gain a better life through better changes. The current education should be able to prepare students in facing the globalization, where students can be more active, creative, and innovative. However, the education in Indonesia is currently in the process of improving its quality. The government is implementing a new curriculum, namely the 2013 curriculum, with a scientific approach.

With regard to the issue of scientific approach, it has been implemented at various levels of school: in elementary school, middle school, and senior high school. It is stated by Saefudin \& Berdiati (2016: 43) that scientific approach does not only focus on the learning outcomes as the main goal, but another important aspect is the learning process, therefore it is emphasized on the process. Further, in scientific approach, the students are required to be more active in the learning process. Thereby, its process is student-centered while the teacher acts as a facilitator, presents the materials, prepares a syllabus, designs the learning process, and coordinates students during the learning process.

With regard to the implementation of the 2013 curriculum, one of the important aspects to be prepared is the human resources, particularly creative and qualified teachers. In addition, another aspect is the fulfillment of the student learning facilities that can support the learning process. Yet, as found by the researcher, the implementation of the 2013 curriculum with a scientific approach has not been fully implemented. Some problems were found. First, the learning process was still teacher-centered. Second, the method of teaching and delivering the material was less attractive and still using the lecturing model, so that the students felt bored and less interested in the learning process. Third, the learning outcomes obtained by the students were still lack. As found by the researcher in SMAN 1 Ngaglik, the students obtained the mid test scores on geography subject were still below the minimum learning mastery standard (75.00), in this case, the average score of the students' mid test is 60.00 . Therefore, to solve these problems, it is necessary to imply the scientific learning approach through Project-Based Learning and Problem-Based learning models on geography subject.

Sani (2013: 171) states that "Project-Based Learning refers to students designing, planning and carrying out an extended project that produces a public-exhibited output such as a product, publication, or presentation". In addition, Krauss \& boss (2013: viii) claims that Project-Based learning model can create a meaningful learning experience which is easy to be remembered by the students, it is due to its notion that teachers not only provide learning material but provide concrete examples of real problems. Another point is asserted by Hosnan (2014: 202-203) that Project-Based Learning is a systematic learning model that involves students in the learning process and skill development through complex exploration processes and assignments, and produces a product at the end of the learning process. Further, Fathurrohman (2015: 119) defines Project-Based Learning as a learning model that uses a project or activity in the students' learning process for achieving the learning goals and fostering students' knowledge and skills. 
Meanwhile, Problem-Based Learning (PBL) is a teaching model which tries to ensure that students learn by working together in a group to examine real life problems (Tok, 2016: 154). In this model, as emphasized by Duch, Groh, \& Allen (2001: 6), the complexity of real life problems is used to motivate students for identifying and examining the concepts and principles in solving the problems. The students are set up to work together as a team, collaborate the collective skills in communicating, and integrate the information. Therefore, by implementing this interactive and innovative learning model, it is expected to improve students' learning outcomes. Last, Alavi (1995: 29) proposes that a structured processing framework is very beneficial for students at the beginning of the problem-based learning process, in other words, mastering the framework is as the first valuable point before beginning to engage in more complex problems that significantly lead them to their ability to make sophisticated clinical judgments before they graduate.

Hereinafter, it cannot be denied that, in one class, there are various kinds of students' characteristics. In accordance to the notion of 'Locus of Control', students' characteristics are divided into 'Introvert' and 'Extrovert'. Kreitner \& Kinicki (2005: 155) asserts that:

"Locus of Control is Individuals who have an external locus of control tendency are individuals who have confidence that their performance is the result of events that occur outside of their direct control. the results achieved by the internal locus of control are thought to originate from his or her own activities. Whereas in the individual locus of control external consider that the success achieved is controlled from the surrounding circumstances. A person who has an internal locus of control will see the world as predictable, and individual behavior plays a role in it. In individuals who have external locus of control will view the world as something unpredictable, so also in achieving goals so that individual behavior will not have a role in it."

To sum up, the implementation of an appropriate learning model which is in accordance to each student's Locus of Control is expected to improve students' learning outcomes. Therefore, this study is aimed at determining the effectiveness of Project-based Learning and Problem-based Learning models towards geography learning outcomes in terms of students' Locus of Control.

\section{The Method}

This study used experiment method, by utilizing the $2 \times 2$ factorial design. The population was all the students of SMAN 1 Ngaglik. The samples were 60 students of XI IPS class selected randomly, consisting of 32 students in the experimental group of Problem-Based Learning model and 28 students in the Project-Based Learning model. The instruments of the data collection were questionnaires and learning outcomes tests. The data were analyzed using Two Ways ANOVA, at the significance level $\alpha=0.05$. The Two- 
way ANOVA (Two Ways Analysis of Variance), as stated by Riduwan (2016: 222), is used to examine the comparison hypothesis consisting of more than two samples, in which each sample consists of two or more types conjointly.

\section{Result And Discussion}

\section{Learning Outcomes Description}

With regard to the learning outcomes, the data were obtained from tests which were in the forms of pre-test (before the treatment) and post-test (after the treatment). The test contains 10 multiple choice and 2 essay questions. The following is the results of the geography learning outcomes which are in the forms of pre-test and post-test on the group of students who were given Project-Based learning and Problem-Based Learning models in SMAN 1 Ngaglik;

Table 1. Data Description of Geography Learning Outcomes

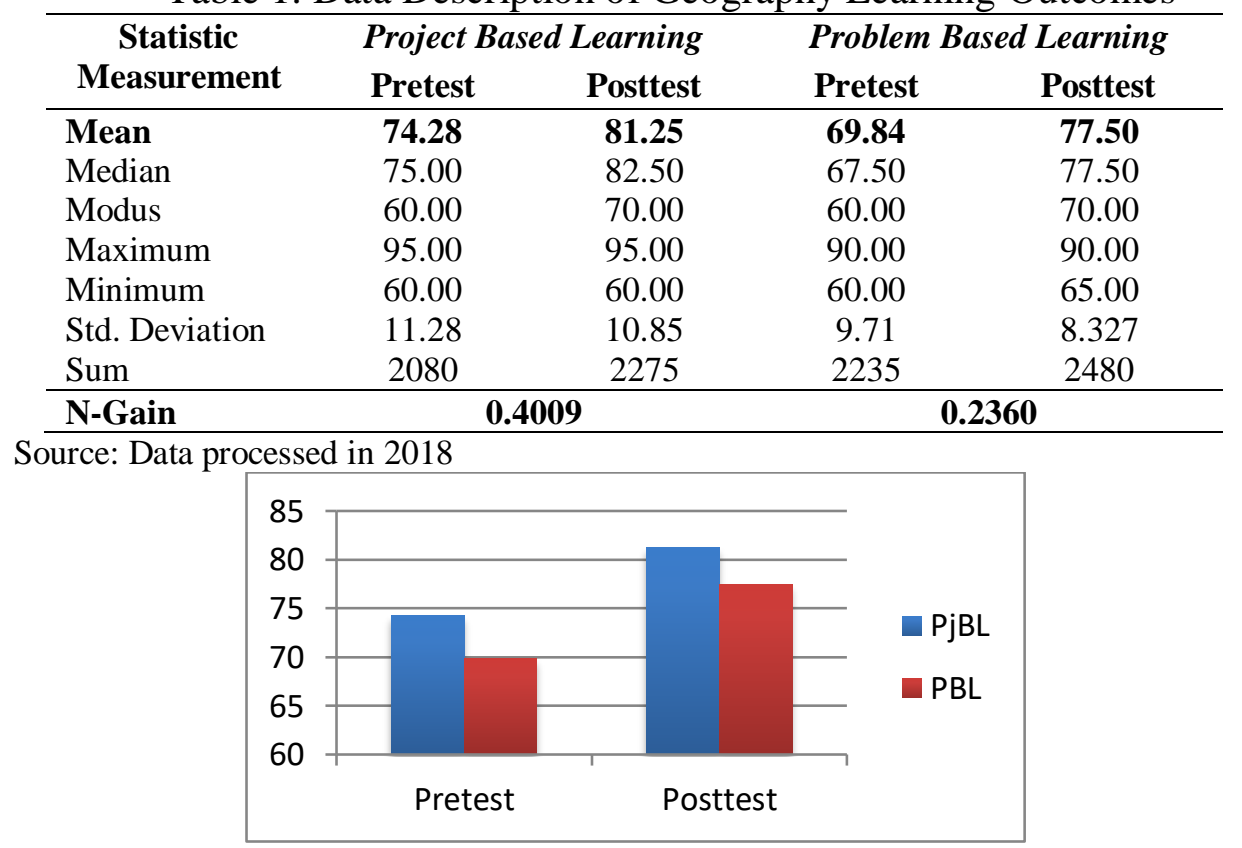

Figure 1. Average Curve of Geography Learning Outcomes of Project-Based Learning and Problem-Based Learning Models.

As shown in Table 1, the result of the students' pre-test before implementing ProjectBased Learning model is: the mean of 74.28; the median of 75.00; the modus of 60.00; the maximum score of 95; the minimum of 60 (SD: 11.28). Mean while, the result of the posttest after implementing Project-Based Learning model is: 81,250 (mean), 82.50 (median), 70 (modus), 95 (maximum score), 60 (minimum score), and 10.85 (standard deviation). And, it also presents that the result of the pre-test before implementing Problem-Based Learning model obtains the mean of 69.84, the median of 67.50, and the modus of 60, where the maximum score is 90 and the minimum is 60 (SD: 9.71). Meanwhile, the result of the posttest after implementing Problem-Based Learning model shows improvements: the mean is 77.50 ; the median is 77.50; and the modus is 70 , where the maximum score is 90 , the minimum is 65 , and the standard deviation is 8.32 . To conclude, in accordance to the mean 
score of the post-test, students gained a better improvement in the group that has been given the treatment of Project-Based Learning model which is an average score of 81.25.

\section{Locus of Control (LoC) Description}

With regard to the student's LoC, it was considered through a questionnaire containing 15 questions, in which the student was asked to choose 'yes or no' answers. The following is the result of the LoC questionnaire test on the group of students who were given the implementation of Project-Based Learning and Problem-Based Learning models in SMAN 1 Ngaglik;

\begin{tabular}{lcccc}
\multicolumn{2}{c}{ Table 2. Data Description of Students' } & LoC in SMAN 1 Ngaglik \\
\hline & \multicolumn{2}{c}{ Project Based Learning } & \multicolumn{2}{c}{ Problem Based Learning } \\
& Introvert & Ekstrovert & Introvert & Ekstrovert \\
\hline Frequency & 11 & $\mathbf{1 7}$ & 14 & $\mathbf{1 8}$ \\
Percent & 39.3 & 60.7 & 43.8 & 56.3 \\
N-Gain & $\mathbf{0 . 2 6 9 0}$ & $\mathbf{0 . 4 8 6 3}$ & $\mathbf{0 . 2 3 6 9}$ & $\mathbf{0 . 2 3 5 4}$ \\
\hline
\end{tabular}

Source: Data processed in 2018

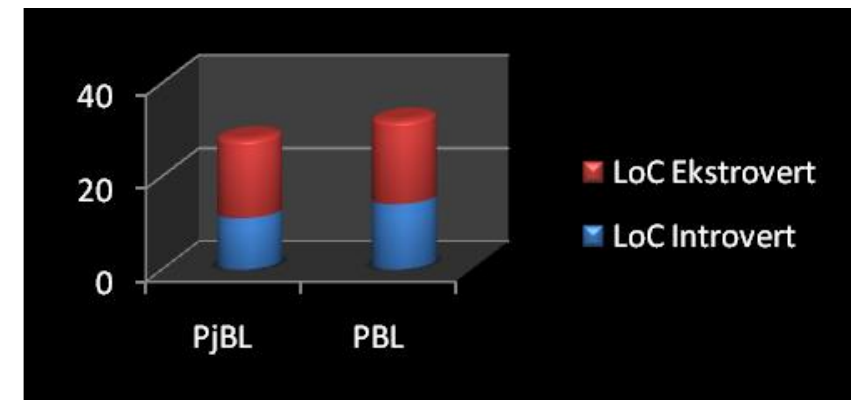

Figure 2. Graphic Introvert and Extrovert Students' LoC

It can be seen from the data in Table 2 that the group given the implementation of Project-Based Learning model consists of 17 extrovert students with a percentage of $60.7 \%$, and 11 introvert students of 39.3\%. As also seen in Table 2, the group given the implementation of Problem-Based Learning model consists of 18 extrovert students of $56.3 \%$ and 14 introvert students of $43.8 \%$. These results come to draw a conclusion that most of the students in SMAN 1 Ngaglik given the implementation of Project-Based Learning and Problem-Based Learning models have extrovert personality, namely: 17 and 18 students.

\section{Hypothesis Test Result}

The interaction between the learning models and students' locus of control toward geography learning outcomes is presented as follows:

Table 3. The Result of Two Way ANOVA Test between the Learning Models and Students' Locus of Control towards Geography Learning Outcomes

\begin{tabular}{|c|c|c|c|c|c|c|c|}
\hline \multirow[t]{2}{*}{ Model } & \multicolumn{2}{|c|}{ Average Score } & \multirow{2}{*}{$\begin{array}{l}\text { Sum of } \\
\text { Square }\end{array}$} & \multirow[t]{2}{*}{ Df } & \multirow{2}{*}{$\begin{array}{c}\text { Mean } \\
\text { Square }\end{array}$} & \multirow[t]{2}{*}{$\mathbf{F}$} & \multirow[t]{2}{*}{$\mathbf{P}$} \\
\hline & Ekstrovert & Introvert & & & & & \\
\hline $\mathrm{PjBL}$ & 87.64 & 76.36 & 362.36 & 1 & 362.363 & 5.488 & $0.023<0.05$ \\
\hline
\end{tabular}


Nur Hafidah Yuniar Sari, et all / GEOSI Vol 3. No. 3 (2018) 16-25

$\frac{78.05}{\text { PBL }}$

Looking at Table 3, it is apparent that the $F_{\text {cal }}$ is higher than $F_{\text {std }}$, namely: $5.488>$ 4.00. In this case, Ho is rejected whereas $\mathrm{Ha}$ is accepted, which means that there is an interaction between the learning models and students' locus of control towards the learning outcomes in SMAN 1 Ngaglik. And, the value of the probability is $0.023<0.05$. In summary, this result shows that there is an influence between the learning models and locus of control towards the students' learning outcomes.

\section{DISCUSSION}

Discussion

Problem Based Learning and Project Based Learning models are scientific learning models applied to the 2013 curriculum. The model encouraged students to play an active role in the learning process. Students were given the opportunity to do insight exploration, so that it could spur them to think creatively and innovatively. The application of the learning model was expected to improve student learning outcomes. The application of the learning model could be adjusted to each student's locus of control, both locus of control introvert and extroverted, so that the learning outcomes of students both introverted and extroverted could increase and the learning outcomes could be maximized.

The value of $F_{\text {count }}>\mathrm{F}$ table was equal to 5.488> 4.00, where Ho was rejected and Ha was accepted, which means there was an interaction between the learning model and Locus of Control on student learning outcomes in SMAN 1 Ngaglik. The probability value between the learning model and Locus of Control on learning outcomes was equal to 0.023 $<0.05$, so it could be seen that there was an influence between the learning model and Locus of Control on student learning outcomes. Judging from the results of the mean, we could know that students who were given treatment with the application of the Project Based Learning model got a better value of 81.25. The majority of students had Extrovert Locus of Control both in the class given the application of the Problem Based Learning and Project Based Learning models as many as 17 students and 18 students.

The results of the study were in line with the research conducted by Noviarda (2015), which stated that there were significant differences in learning outcomes between students given treatment by applying the Project Based Learning model to students who were given the treatment by applying the Expository model. The results of the research from Prahesti (2017) were that there was an influence between the Problem Based Learning and Project Based Learning models on students' learning outcomes.

Susanti, Rahma \& Monalisa (2017), explained that there were differences in mathematical problem solving abilities of students who had locus of control introverts with mathematical problem solving abilities that had extroverted locus of control. The mathematical problem solving ability of groups of students with locus of control introverts was better than the mathematical problem solving abilities of groups of students with extroverted locus of control.

The results of the study from Syatriadin (2017) were that students with locus of control introverts had better performance on average than extroverts. Pangestika (2015) stated that students with extroverted locus of control in the inquiry model group were more effective in improving geography learning outcomes. The results of the study from 
Wicaksono (2016), which states that there was a significant effect of Problem Based Learning, Discovery Learning and Conventional learning models on geography learning outcomes on disaster mitigation and adaptation material in Wonogiri District Public High School.

Santria (2018), there was no difference in effectiveness between the project-based learning model and problem-based learning in terms of student achievement, mathematical communication skills and student interpersonal abilities. Maysara (2016), the results of this study indicated that with the application of the Problem Based Learning model to the subject of an effective colloid system with an N-gain score of 0.64 and the chemistry learning outcomes of students increased with the average score of 76.

Sari (2018), the results of the study were as follows: (1) There was a difference in effectiveness between the PjBL and PBL learning models for improving geography learning outcomes ( $F_{\text {count: }}$ 6.746> $\left.F_{\text {table: }} 4.00\right)$, PjBL Model was more effective in improving geography learning outcomes, N-Gain: 0.4009 or medium category. (2) There was no difference in the effectiveness of geography learning outcomes between students applying the PjBL and PBL models in the LoC Introverted group ( $\mathrm{T}_{\text {count }}: 0.069<\mathrm{T}_{\text {table: }}$ 4.00). The effective LoC introverted group was treated well with the PjBL and PBL learning models to improve students' learning outcomes, N-Gain: 0.2690 and 0.164 or low effectiveness categories. (3) There were differences in the effectiveness of geography learning outcomes between students applying the PjBL and PBL models in the LoC extroverted group ( $\mathrm{T}_{\text {count: }}$ 4.848> $\mathrm{T}_{\text {table: }}$ 4.00). LoC extroverted groups were more effectively treated with $\mathrm{PjBL}$ learning models to improve students' learning outcomes, N-Gain: 0.4863 or moderate effectiveness categories. (4) There was an interaction between the model and locus of control on learning outcomes ( $F_{\text {count: }}$ 6.096> $F_{\text {table: }}$ 4.00).

\section{Conclusion}

The third hypothesis states that there is an interaction between the models and students' locus of control towards the learning outcomes. The result shows that $F_{c a l}$ is higher than $\mathrm{F}_{\text {std }}: 5.488>4.00$, in which the value of the probability is $0.023<0.05$. In this case, Ho is rejected whereas $\mathrm{Ha}$ is accepted, which means that there is an interaction between the learning models and students' locus of control towards the learning outcomes in SMAN 1 Ngaglik. Judging from the post-test mean score, the students obtained better grades in the group that has been given the treatment of Project-Based Learning model, in which the mean score is 81.25 . And, it is also found that most of the students of SMAN 1 Ngaglik have extrovert personality in the group which was given the treatment of ProjectBased Learning and Problem-Based Learning models, namely: 17 students and 18 students.

\section{REFERENCES}

Akdeniz, C., Bacanli, H., Baysen, E. Cakmak, M., Çeliköz, N., Doğruer, N., Eristi, B., Erisen, Y., Eyyam, R., Gündoğdu, K., Karatas, E., Karatas, S., Kaybasi, Y., Kilic, D., Kurnaz. A., Menivis, I., Özerbaş, M. A., Özü, O., Silman, F., Sünbül, A. M., Sahin, M., Tok, H., Yalin, H. I. Ed: Kaya, Z., Akdemir, S. (2016). Learning and Teaching: Theories, Approaches and Models. Tukiye: Çözüm Eğitim Yayıncılık. Retrived from: https://www.researchgate.net/publication/304119354, 14 September 
2018.

Alavi, C. (1995). Problem-Based Learning in a Health Sciences Curriculum. London: Routledge. Retrived from: http://en.booksee.org/s/?q=problem+based+learning\&t=0, diakses pada tanggal 16 september 2018.

Duch, B.J., Groh, S.E., Allen, E.D. (2001). A Pratical "How To" for Teaching Undergraduate Courses in Any Disipline: The Power of Problem Based Learning. Virginia: Stylus Publishing, LLC. Retrived from: http://en.booksee.org/s/?q=problem+based+learning\&t=0, diakses pada tanggal 15 september.

Fathurrohman, M. (2015). Model-model Pembelajaran Inovatif. Yogyakarta: Ar-Ruzz Media.

Hosnan, M. (2014). Pendekatan Saintifik dan Konsektual Dalam Pembelajaran Abad 21: Kunci Sukses Implementasi Kurikulum 2013. Bogor: Ghalia Indonesia.

Krauss, J. \& Boss, S. (2013). Thinking Through Project-Based Learning, Guiding Deeper Inquiry. USA: A Sage Company.

Kreitner, R., dan Kinicki, A. (2005). Perilaku Organisasi. Jakarta : Salemba Empat.

Maysara. (2016). "The Effectiveness Of Problem Based Learning (PBL) Model On Students' Learning Outcomes At Class Xi Ipa 2 Of Senior High School 5 South Konawe On The Subject Of Colloid System". International Journal of Education and Research, 4(7). Halu Oleo University, Kampus Bumi Tridharma. Internasional Journal of Education and Research. ISSN: 2411-5681.

Pangestika, R. P. (2015). "Keefektifan Model Inquiry dan Discovery Dengan Pendekatan Saintifik Dalam Pembelajaran Geografi Ditinjau Dari Locus of Control di SMA Kabupaten Pemalang. Tesis, tidak diterbitkan. Universitas Negeri Yogyakarta.

Prahesti, H.C . (2017). Eksperimen Model Pembelajaran Problem Based Learning Dan Project Based Learning Pada Pembelajaran Matematika Terhadap Hasil Belajar Ditinjau Dari Keaktifan Belajar Siswa. Skripsi, Diterbitkan. Universitas Muhammadiyah Surakarta. Retrived from: http://eprints.ums.ac.id, diakses pada tanggal 17 Oktober 2018.

Purwanto. (2013). Evaluasi Hasil Belajar. Yogyakarta: Pustaka Pelajar.

Riduwan. (2012). Dasar-Dasar Statistika. Bandung: Alfabeta.

Saefuddin. A. \& Berdiati, I. (2016). Pembelajaran Efektif. Bandung: Rosda.

Sani, R. A. (2017). Pembelajaran Saintifik Untuk Implementasi Kurikulum 2013. Jakarta: Bumi Aksara.

Santria, U. (2018). Efektifitas Model Project Based Learning dan Model Problem-Based Learning Ditinjau dari Prestasi Belajar, Kemampuan Komunikasi Matematis, dan Kemampuan Interpersonal Siswa Materi Statistika dan Peluang Kelas VIII. Tesis, tidak diterbitkan. Universitas Negeri Yogyakarta,Yogyakarta. 
Sari, N. H. Y. (2018). Efektifitas Model Pembelajaran PJBL Dan PBL Untuk Meningkatan Hasil Belajar Geografi Ditinjau dari Locus Of Control Siswa Sma Negeri Ngaglik, DIY. Tesis. Program Studi Pendidikan Geografi. Program Pascasarjana. Universitas Negeri Yogyakarta.

Susanti, D., Rahma, R.M., Monalisa. (2017). Pengaruh Locus of Control Terhadap Kemampuan Pemecahan Masalah Matematika. Journal Nasional Pendidikan Matematika. Retrived from: www.researchgate.net, diakses pada tanggal 17 Oktober 2018.

Syatriadin. (2017). Locus of Control: Teori Temuan Penelitian Dan Reorientasinya Dalam Manajemen Penanganan Kesulitan Belajar Peserta Didik. Jurnal Pendidikan Dasar. 1(1). e-ISSN 2579-6194; 144-164.

Wicaksono, U. (2016). Keefektifan Model Pembelajaran Problem Based Learning dan Discovery Learning Berdasarkan Adversity Quotient terhadap Hasil Belajar Geografi SMA di Kabupaten Wonogiri. Tesis, tidak diterbitkan. Universitas Negeri Yogyakarta.

versity 